\title{
Beyond the Persecuting Society
}


This page intentionally left blank 


\title{
Beyond the \\ Persecuting Society
}

Religious Toleration

Before the Enlightenment

\author{
edited by \\ John Christian Laursen \\ and Cary J. Nederman
}

\section{$\overline{\text { PENN }}$}

University of Pennsylvania Press

Philadelphia 
Copyright (C) 1998 University of Pennsylvania Press

All rights reserved

Printed in the United States of America on acid-free paper

IO $9 \begin{array}{lllllllll} & 8 & 7 & 6 & 5 & 4 & 3 & 2 & \text { I }\end{array}$

Published by

University of Pennsylvania Press

Philadelphia, Pennsylvania I9104-40II

Library of Congress Cataloging-in-Publication Data

Beyond the persecuting society : religious toleration before the Enlightenment / edited by John Christian Laursen and Cary J. Nederman.

p. $\mathrm{cm}$.

Includes bibliographical references and index.

ISBN 0-8I22-333I-X (alk. paper). - ISBN 0-8122-I567-2 (pbk. : alk. paper)

I. Religious tolerance-History. I. Laursen, John Christian. II. Nederman, Cary J.

BRI6IO.B48 1997

29I.I'772'09-dc2I 